Milan Fil'a,

Ph.D., Associate Professor, Constantine the Philosopher University in Nitra, Slovak Republic

ORCID ID, 0000-0001-7655-1229

email:mfila@ukf.sk

Michal Levicky,

Ph.D., Constantine the Philosopher University in Nitra, Slovak Republic

ORCID ID, 0000-0002-5297-1664

email:mlevicky@ukf.sk

Ladislav Mura,

Ph.D., Associate Professor, Pan-European University in Bratislava, Slovak Republic

ORCID ID, 0000-0002-2453-8740

email: ladislav.mura@gmail.com

Milan Maros,

Ph.D., Constantine the Philosopher University in Nitra, Slovak Republic

ORCID ID, 0000-0002-3818-2132

email: mfila@ukf.sk

Marcela Korenkova,

Ph.D., Constantine the Philosopher University in Nitra, Slovak Republic

ORCID ID, 0000-0001-5811-0876

email: mkorenkova@ukf.sk

Correspondence author: ladislav.mura@gmail.com

\title{
INNOVATIONS FOR BUSINESS MANAGEMENT: MOTIVATION AND BARRIERS
}

Abstract. The business sector represents one of the most important parts of the modern economy. It creates and secures most products and services, contributing to most of the sales tax revenues. Business development is not possible without creating a favourable business environment and suitable conditions for creating and entering new business into the market. This paper focuses on the evaluation of some business environment factors in starting a business. Attention is attended to the business environment and funding activities management, including the managerial assessment of proactive, innovative, and business-supporting activities. Besides, this study encompasses the issues of obstacles and barriers to starting a business. The interest of the article is to point out the state and problems in the field of start-up entrepreneurs and the importance of supporting motivational factors and removing barriers by improving the business environment. Methodological tools of the research are classical methods of science analytics, synthesis, and data selection. The basic heuristic approach consists of professional literature on the subject matter, and secondary sources obtained from European Commission, Eurostat - Flash Barometer, and the World Bank to monitor selected indicators of the business environment and SMEs in Slovakia, EU-27 countries and the world. The primary information was represented with the questionnaire-based survey conducted throughout the Slovak Republic, in which a total count of 426 respondents participated. For hypothesis testing, the Friedman Test, Kolmogorov - Smirnov test, and Kruskal - Wallis test was used. The empiric results confirmed the significant differences between motivational factors for starting doing business. At the same time, there are still significant barriers to enter the business in Slovakia, which considerably limit the further development of doing business in Slovakia. The article provides recommendations for improving the business environment's current status and entering into business in the Slovak Republic.

Keywords: small and medium entrepreneurship, innovations, business barriers and opportunities, business management.

Cite as: Fila, M., Levicky, M., Mura, L., Maros, M., \& Korenkova, M. (2020). Innovations for Business Management: Motivation and Barriers. Marketing and Management of Innovations, 4, 266-278. http://doi.org/10.21272/mmi.2020.4-22 
Introduction. The entrepreneurship is considered to be one of the fundamental manifestations of a free modern economy based on market principles. The business sector creates and secures most products and services. The importance of business is also unquestionable in terms of GDP (Gross Domestic Product) and jobs. At the same time, it contributes to most of the sales tax revenues. However, further business development is not possible without creating a favourable business environment and suitable conditions for creating and entering new business into the market as easily as possible. On the other hand, entering the business environment is the most vulnerable part of doing business because many new enterprises are closing down in a few years after starting with their entrepreneurship activities. That makes it all the more important to focus on this group of entrepreneurs, which is usually an essential carrier of innovation and new trends. The main goal of the presented scientific contribution is to identify the key business environment factors of motivation and barriers to entering the business in Slovakia. Startup entrepreneurs are essential for maintaining the economic growth and competitiveness of the Slovak economy in the global context.

Literature Review. At the end of the eighties, the fundamental political, social and economic changes in Europe were continually transferred to the economy at the macro and the microlevels of individual and business entities, which naturally reflected in fundamental shifts in international business. The Slovak Republic was also part of this movement. The Act No. 513/1991 Coll Commercial Code of the Slovak Republic defines entrepreneurship in the Slovak Republic conditions as a continuous activity carried out by an entrepreneur in his behalf and on his responsibility to make a profit. From an economic point of view, the business is considered a combination of economic resources and activities to increase the original value, i. the dynamic process of creating a certain value (Junger, 2001). Psychologists approach the study of business as an activity that is motivated by the need to get something, to achieve something, to try something, to fulfil something (Srpova and Rehor, 2010). The study (Timmons, 2002) supports this statement which defines entrepreneurship as a way of thinking and acting, which means an obsession with opportunities, a holistic approach, and all harmonized with leadership. Further Bohm-Klein (2015) points to the definition linking the economic and psychological aspect, according to which entrepreneurship is a purposeful human activity carried out to satisfy the entrepreneur's own needs by satisfying the needs of others. A surprising finding is that the reasons why people start a business are published in professional literature to a limited extent. In turn, Papula and Papulova (2002) and Peracek (2019) in the earlier book publication «Entrepreneurship» state that the most common motives that lead entrepreneurs to entrepreneurship are such as:

- profit;

- professional, self-realization and emotional motives of business;

- social motives for business;

- external incentives for business development.

According to Thompson and Penny (2013), an individual intends to undertake a person's self-affirming belief intending to start a new business attempt and consciously plans to do in the future. Furthermore, the author stated that this moment could be close or not precisely determined or never be reached in the future. Profit is not the primary motivating factor for the business, while it is only the result of business activity. Business motivation is based on the psychological tendencies, preferences, and ideas of the entrepreneur (Schumpeter, 1983). At the same time, the authors put the profit in the first place, that is not a key motive for starting a business. Nevertheless, this claim is also supported by research carried out by GE Money Bank in the Czech Republic (PwC, 2010). Special attention is paid to the motivations for women's entrepreneurship. The authors of the researches (Karnreungsiri and Praditsuwan, 2017; Cavada et al., 2017; Fosic et al., 2017) agreed that the main motivating factors, in this case, are the passion in the field of business and the need for income improvement. Interestingly, sociologists from Johns Hopkins University researched in the late 1960s on 7,948 American students. The obtained results showed that 
$78 \%$ of respondents embracing the importance to find meaning in their lives. The goal of only $16 \%$ was to make as much money as possible, as pointed out by Toman (2010) in his book. Therefore, these findings exacerbate that profit is not a decisive motive for starting a business. In turn, Ketko and Akimova (2016) pointed out that entrepreneurs were motivated by their inner comfort, self-esteem, success, opportunity to have freedom, the chance to meet their personal goals, and financial security (Koraus et al., 2019; Koraus et al., 2017).

From the presented opinions of the authors as well as several realized kinds of research it is clear that the key motivators for entering the business are those positively represented by the emotional desire for self-realization and the need for independence, but also a rational component in the form of expected profit and higher income compared to traditional employment. However, as Thompson and Penny (2013) argued, the intensity of the intention to do business is different for each person. That could vary depending on different times and the circumstances. Barriers to starting a business represent an important special part of the business environment study, as their existence coul blocks new business establishment and new industries, innovative products, and services. Besides, that could lead to a loss of competitiveness and economic decline of the country's or region's economy. Mushtaq (2017) argued that there were three key barriers to starting a successful business that every new entrepreneur should address, as follows:

- money;

- fear of failure;

- weak plan.

Kanniainen and Poutvaara (2007) identified several distortions that create barriers to business. They identified the input costs caused by regulation, trade union wage policy, and the inefficiency of knowledge transfer between generations of entrepreneurs to be the main obstacles. According to the consulting company Altaxo (2015), the entry and exit barriers are influenced by the degree of competition in the field. Cupido (2003) examined business barriers in the Western Cape, South Africa. His findings suggested that the lack of managerial skills in small businesses and the bureaucracy difficulties a business has to deal with were among the key factors. Sandhu et al. (2011) considered the lack of willingness to take risks and the fear of failure to be barriers to starting a business. Bertan (2020) claimed that it was quite important to present the different characteristics as different activities with an innovative and creative approach. Klapper et al. (2006) conducted a comprehensive study on the impact of market entry regulation on creating new firms. They also found that costly regulations (regulatory costs) hinder new firms' creation, especially in sectors that should have a naturally high input. Ramayah and Harun (2005) argued that access to capital was one of the most difficult business growth barriers. Martins (2004) and Srovnalíkova (2017) discussed economic and financial barriers while argued that many entrepreneurs had difficulty obtaining credit. A competitive struggle characterizes the Business environment (Mura and Rozsa, 2013). Qunlian (2011) argued that the right business environment is the foundation of business success and an unsuitable business environment. Besides, the lack of political support systems is an obstacle to starting a new business. Other institutional barriers, such as lack of government assistance, infrastructure issues, inadequate laws, and corruption, were also mentioned in various ways by Sandhu et al. (2011). In today's digital society, the low level of digitization of state administration services is also a barrier to entry into the business. Blstakova et al. (2020) found that the present implementation of digitization is very important for the business's future sustainability.

Methodology and research methods. Elaboration of this scientific paper implements the theoretical knowledge and information obtained from available domestic and foreign scientific sources consisting primarily of secondary information sources. The secondary sources of information were data and knowledge obtained through the study; processing and analysis of scientific and professional publications; and available statistics of the European Commission, Eurostat - Flash Barometer, and the World Bank to monitor selected indicators of the business environment and SMEs in Slovakia, EU-27 countries and the 
world. The primary information was represented by the questionnaire-based survey conducted throughout the Slovak Republic to scientifically identify the current state of perception of attitudes to the business environment and business entry issues while also focusing on identifying key barriers. For verifying the representativeness of the selected file of the respondents, Pearson's chi-squared goodness of fit statistical test was used. The formula expression follows:

$$
\begin{aligned}
& \chi^{2}=\sum_{i=1}^{r} \frac{\left(n_{i}-e_{i}\right)^{2}}{e_{i}} \\
& \text { where: } n_{i} \text {-empirical frequency; } e_{i} \text { - theoretical frequency. }
\end{aligned}
$$

This statistic asymptotically approaches a $\chi^{2}$ division with the $\mathrm{r}-1$ degrees of freedom. It is based on the frequency table and tests the null statistical hypothesis stating that the numbers in the individual categories are equal to the expected (theoretical) numbers (Rimarcík, 2007).

In this case, the categories are gender and regional population structure. Based on the calculation of the tested characteristic $(\mathrm{TCH})$ and its subsequent comparison with the critical value $(\mathrm{CV})$, it is possible to confirm the established hypothesis $\mathrm{H} 0$. Thus, the respondents' selected file is representative concerning gender and regional structure of the Slovak Republic population.

The primary scientific research defines two hypotheses:

- Hypothesis A: It is assumed that there are similar motivational factors for respondents influencing their decision to start a business, so the arrangement is meaningful.

$\mathrm{HO}$ : The mean values of the sample files do not differ, i.e. they acquire similar values (the respondents' answers are evenly distributed).

$\mathrm{H} 1$ : The sample files' mean values differ; they acquire different values (significant deviations).

- Hypothesis B: It is assumed that the respondents significantly prefer (consider it significant) some of the obstacles mentioned above to start a business. Thus, it is possible to demonstrably reduce the demotivation rate of citizens when starting a business by removing it.

$\mathrm{HO}$ : Samples have the same distribution. Their distribution functions are the same.

$\mathrm{H} 1$ : Samples do not have the same distribution; their distribution functions are different.

Using the Friedman Test, Kolmogorov-Smirnov test, and Kruskal-Wallis test allowed testing the mentioned above hypothesis.

The Friedman test is based on two-dimensional table $x_{i j}(i=1, \ldots, n ; j=1, \ldots, k)$ with $n$ rows and $k$ columns. In turn, $n$ represents sample range identical for all samples. Besides, $k$ is a number of tested samples. Null hypothesis tests the conditions of all samples coming from one distribution. Thus, their distribution functions are identical $\mathrm{H} 0: \mathrm{F} 1(\mathrm{x})=\mathrm{F} 2(\mathrm{x})=\ldots=\mathrm{Fk}(\mathrm{x})$. Test statistics are calculated via the following formula:

$$
F=\frac{12}{n k(k+1)} R-3 n(k+1)
$$

The alternative hypothesis is accepted on a significance level in case that $F \geq x_{1-\alpha}^{2}(k-1)$ where $x_{1-\alpha}^{2}(k-1)$ represents a critical value of Chi-square distribution $x^{2}$ with $(k-1)$ degrees of freedom (Stiglic, 2009). The Kruskal-Wallis test is a nonparametric equivalent of a one-factor ANOVA. Similarly to the Kolmogorov - Smirnov test, the condition for use is ordinal data, but unlike the mentioned test, it has to be more than 2 independent samples. The formulation of the null hypothesis consists of the mean values of the sample files comparing. Thus, it assumed that the mean values of the analyzed files acquire similar values. Calculation of test characteristic $H$ Kruskal-Wallis test is: 


$$
H=\left(\frac{12}{N *(N+1)} * \sum_{j=1}^{k} \frac{R_{j}^{2}}{n_{j}}\right)-3 *(N+1)
$$

Test characteristic $H$ is compared with a table value, which approximates the $x^{\wedge} 2$ distribution with k1 degrees of freedom. (Horska et al., 2011). The classical methods of science analytics, synthesis and data selection were used to obtain the results and conclusions of the research. Results of the study are presented in graphical and table form supplemented by explaining comments.

Results. Based on the basic economic performance parameters and OECD membership, Slovakia is one of the advanced economies with a GDP of 18,330 USD per capita (2019). However, the economy's performance does not indicate the quality of the business environment or its development. According to the World Banks Doing Business Ranking (2020), Slovakia is currently ranked 45th in overall business environment quality and has stagnated in this area over the long term. However, more important than overall assessment is the development of the conditions for starting to a business for new business entities supporting the future development of the economy and jobs. That is a reason to evaluate this area in the World Bank methodology. The available results demonstrate that Slovakia has significantly deteriorated its ranking in new entrants in the last ten years. While in 2008 the country occupied 48th place, in 2018 up to 127 th place, and in $2020-118^{\text {th }}$ place. In turn, the growth of obligations or barriers to entering the business in Slovakia was among the reasons other countries in this area significantly advanced. Moreover, Slovakia has not changed many procedures. It worth to mention that time needed to establish a business entity prolonged from 12,5 days to 21.5 days.

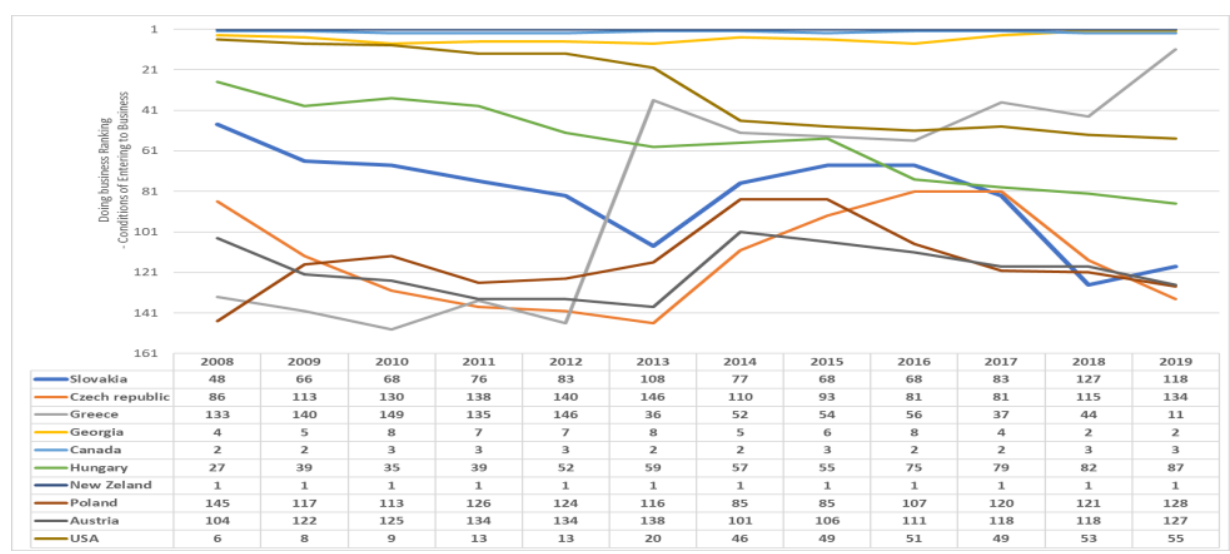

Figure 1. Ranking of Business Entry of Slovakia and Selected Countries (2008 - 2019) Source: developed by the authors on the basis of (World Bank, 2020).

The result of comparative analysis of V4 countries (Hungary, Czech Republic, Poland and Slovakia) showed that Slovakia has a similar position as Hungary or the Czech Republic. However, while Hungary and Slovakia experience stagnation of solutions and a significant slump in the rankings (from 27th to 87th place), the Czech Republic has improved its position after a long-term fall significantly returned to its original positions from 10 years ago. However, recently the Czech Republic suffers a slight decline with 134th place. Significant improvement couldn't also be observed in Poland (shift from 145th place to 128th place) and Austria (shift from 104th to 127th place).From a global perspective, New Zeeland (1st place), Georgia (2nd place) and Canada (3rd place) are the most favourable in terms of business establishment in the long-term. New Zeeland makes it possible to set up a company in one step and one place with the one-stop-shop principle half-day without the need for input (starting) capital. It is possible to do business 
almost immediately, even as a legal entity. It is similar in Georgia, where 1 action and 1 day is sufficient. However, the cost of business establishing stands for 2,1\% of GDP per capita. Input capital is not needed. In Canada, there are two procedures for business establishment, and it takes 1,5 days. There is no necessity in start capital either. By comparison, Greece creates the most favourable conditions for entering the EU-27. However, there are 3 procedures, while the starting capital is not required. In 2019, Greece eased starting a business with reducing the time for commercial company registry and removing the requirement to obtain a tax clearance (World Bank, 2020). Thus, it is possible to establish businesses in Greece in four days.

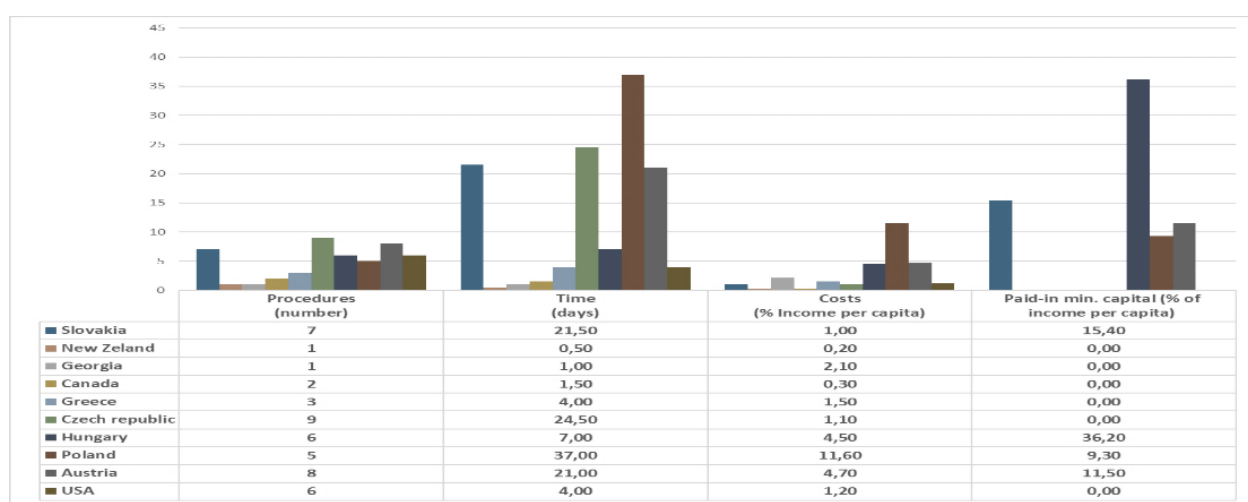

Figure 2. Basic parameters for evaluating business entry conditions in Slovakia and selected Countries (2019)

Source: developed by the authors on the basis of (World Bank, 2020).

Figure 2 demonstrates that V4 countries and Austria have more complicated procedures to establish the business. Thus, the legal entity with limited liability can be established in Hungary in 7 days, in Slovakia in 21,5 days, in the Czech Republic in 24,5 days, in Poland after 37 days. There are establishing costs in all countries mentioned above, except that the Czech Republic cannot establish a company without input capital. This study presents the research focused on the possibilities and barriers to entering the Slovak Republic business. There total count of participated respondents was 426. Based on theoretical knowledge from available sources and other research, 7 basic factors (reasons) were determined. They act as important motivators in the individual's decision to enter the business. Using the Likert scale allowed examining the respondents (residents of the Slovak Republic) examined which of the above options to consider the most important, respectively most important in terms of their motivation in deciding to start a business. Respondents were to assign a significance of 1 to 5 to each factor, with 1 being the least significant factor and 5 - the most important factor. It can be stated that the most significant motivating factor influencing the decision to start a business is the implementation of the idea (average mark 3.89), independence (average mark 3.86), and greater freedom during working hours, i.e. greater flexibility of working time (average mark 3.85). On the contrary, the respondents described the family business's takeover to be the least important (Figure 3). The empirical research results confirm statistically significant differences between the evaluations of individual factors influencing the motivation of the Slovak Republic population to enter the business. 


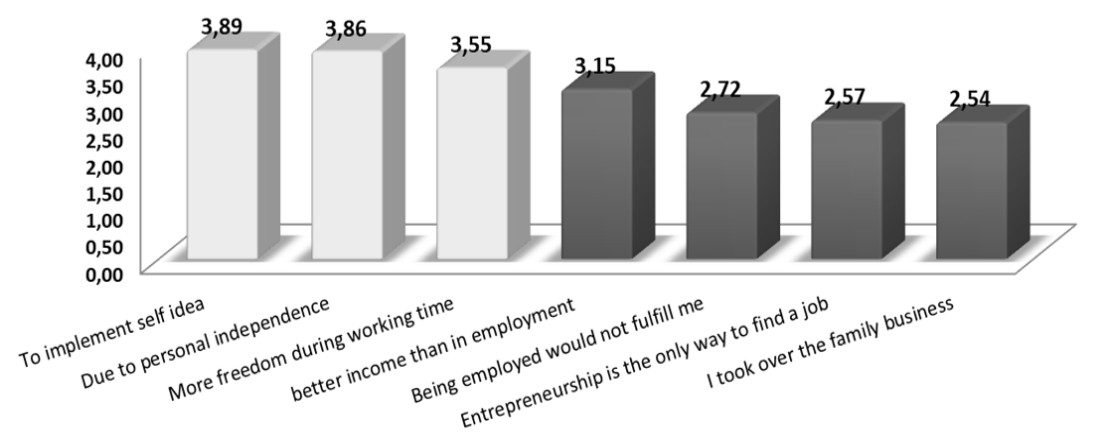

Figure 3. Motivators of entry into the business

Source: developed by the authors.

Based on the Kruskal-Wallis test, it can be stated that there are similar motivational factors among the population of the Slovak Republic influencing their decision to start a business. Therefore, the order of influence is significant, i.e. it is informative and not the result of chance (Table 1).

Table 1. Kruskal-Wallis Test (Motivators of entry into the business)

\begin{tabular}{cc}
\hline \multicolumn{2}{c}{ Kruskal-Wallis Test } \\
\hline Chi-Square & 402,5648 \\
DF & 6 \\
\hline Pr > Chi-Square & $<0,0001$ \\
\hline
\end{tabular}

Source: developed by the authors.

The survey results depict the trends found in the Eurobarometer survey at the level of Slovakia and the EU. Therefore, the main motives for starting a business are psychological aspects (feeling of freedom, realization) followed by financial motives (higher income). There were defined 13 key external barriers to entering the business environment. Each respondent of the research was supposed to put the selected barriers in order and determine their personal preferences. In turn, the rate «1» was the smallest obstacle to enter the business, while «13» - the biggest one. At the same time, it is assumed that respondents in the Slovak Republic would prefer one of these obstacles. In turn, erasing that obstacle, it is possible to improve the business establishment process significantly. Figure 4 shows the highest average ranking on tax and levy burden (average ranking 9.15 - 9.09) and corruption in Slovakia (average ranking 8.79). Besides, significant values were also in categories such as the number of charges, law enforcement in Slovakia and Start-up cost. On the contrary, although it is considered that employers lack skilled labour or long-term infrastructure problems, respondents do not consider these categories as a significant barrier for entering the business environment.

The Friedman test allowed testing the hypothesis that Slovakia inhabitants significantly prefer one or more barriers to enter the Slovak Republic's business environment (if they consider them as more important). After testing the input data, the conclusion showed that Slovakia inhabitants are not indifferent concerning the examined individual barriers. These outcomes are supported by significant statistical differences between the tested categories. 


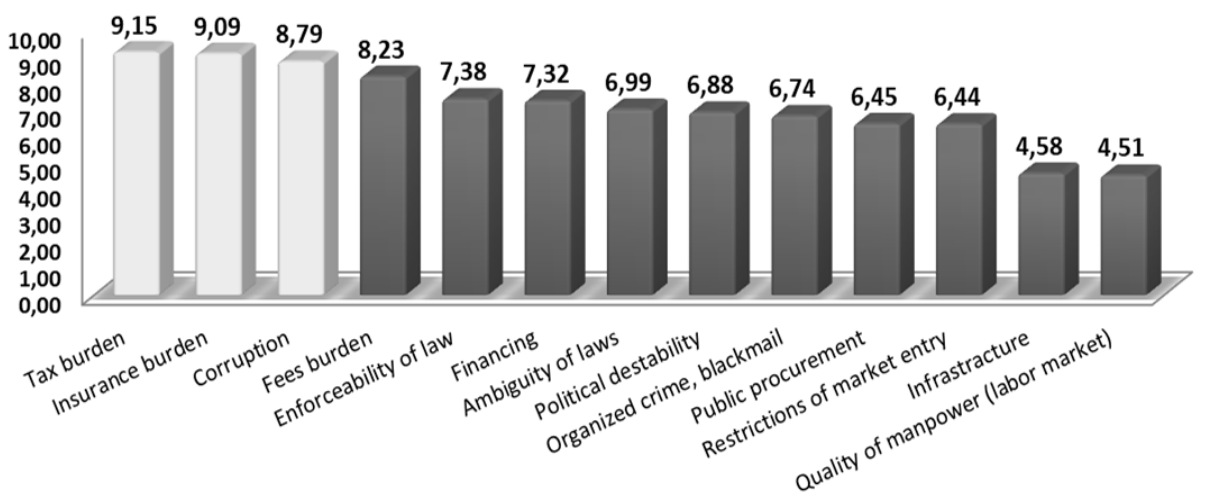

Figure 4. Barriers of entry into the business

Source: developed by the authors.

The results indicated that examined samples were not coming from the same distribution based on the mentioned testing. Therefore, their distribution functions are different, which means that respondents' preferences are significantly different.

Table 2. Friedman's Test (Barriers of entry into the business)

\begin{tabular}{cc}
\hline \multicolumn{2}{c}{ Friedman's Test } \\
\hline Test Characteristics (F calculated) & $-5974,903495$ \\
Critical Value (F tab) & 21,02606982 \\
\hline TCH (F calculated) $<$ CV (F tab) \\
\hline
\end{tabular}

Source: developed by the authors.

The Slovak population perceives some obstacles more than others while confirming that the biggest obstacle to entering the business includes tax and levy burden, charges and financing business establishment. There is also a relatively high fee burden and the cost of entering the business. The survey results suitably complement the Eurobarometer survey, which was oriented on the internal barriers in entering the business. At the level of Slovakia and the EU, the main internal barriers of entering the business are bankruptcy risk, uncertainty of income/job, and property loss risk. Business support, including motives and removal of barriers, is a relatively complex economic and social problem. Besides, it is solved and supplemented from various points of view at the local and international levels. The research results confirm or suitably supplement other professional and scientific studies focused on this issue. The research results by Jakubec et al. (2012) show that positive motives significantly predominate over negative motives in the Slovak Republic. The respondents identified the desire to become independent $(58.64 \%)$ and realize their dream/idea (55.25\%) as the most common motives leading to business. These motives are followed by the so-called negative motives, which include the possibility that respondents' employment did not meet, respectively that they earned little in it (both by $26.85 \%$ ). The secondary importance of profit is also confirmed by Pricewaterhouse Coopers' (PwC) research in 2010 in the Czech Republic, which states that emotional motives prevail over economic reasons when starting a business. According to the obtained results, the most important motive for starting a business is the desire for freedom in decision-making and a passion for a specific own business plan. Only these emotional factors are followed by money and prestige. The present situation could change this status. The globalization of the world economy, its growth, and also the onset of the recession due to the corona crisis have a significant impact on wage trends (Urbaníkova and Stubnova, 2020). The study results also copy the 
trends found in the Flash Eurobarometer survey 354 at Slovakia and the EU level. The main motives for starting a business are psychological aspects (feeling of freedom, realization) followed by financial motives.

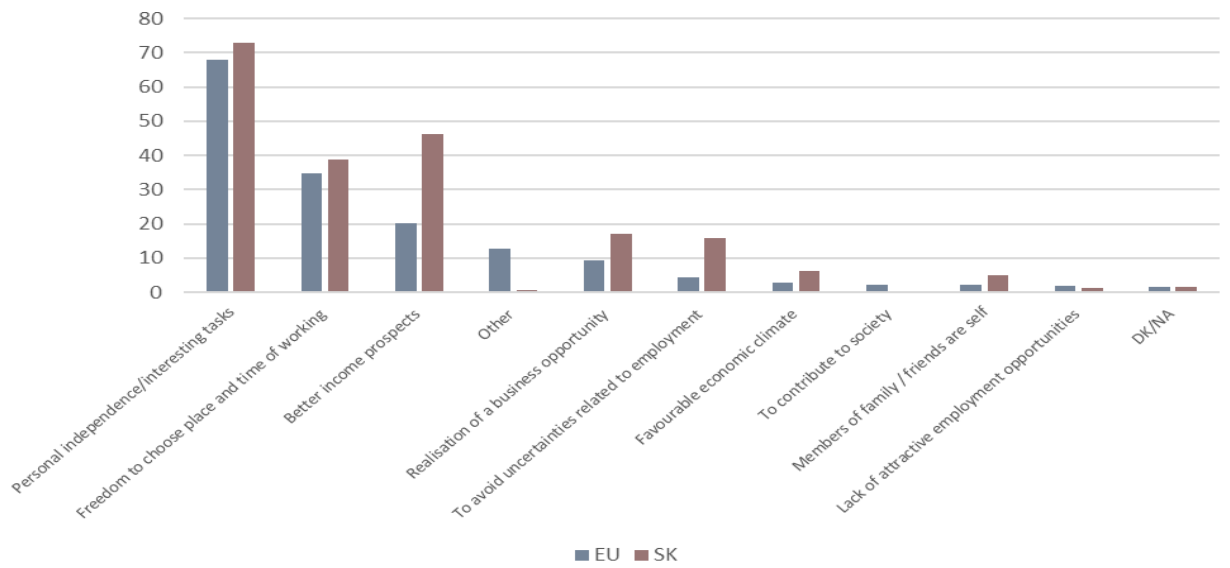

Figure 5. Compares of motivators of entry the business in EU and Slovakia

Source: developed by the authors on the basis of Eurobarometer survey.

Furthermore, empirical research results are supported by the impact of entrepreneurial self-confidence and ambition on entrepreneurial activity (e.g. Hofer et al., 2010; Moriano et al., 2012). The recommendation is to build this self-confidence in people already during the educational process, from primary schools to universities and further education (Lukes et al., 2013).

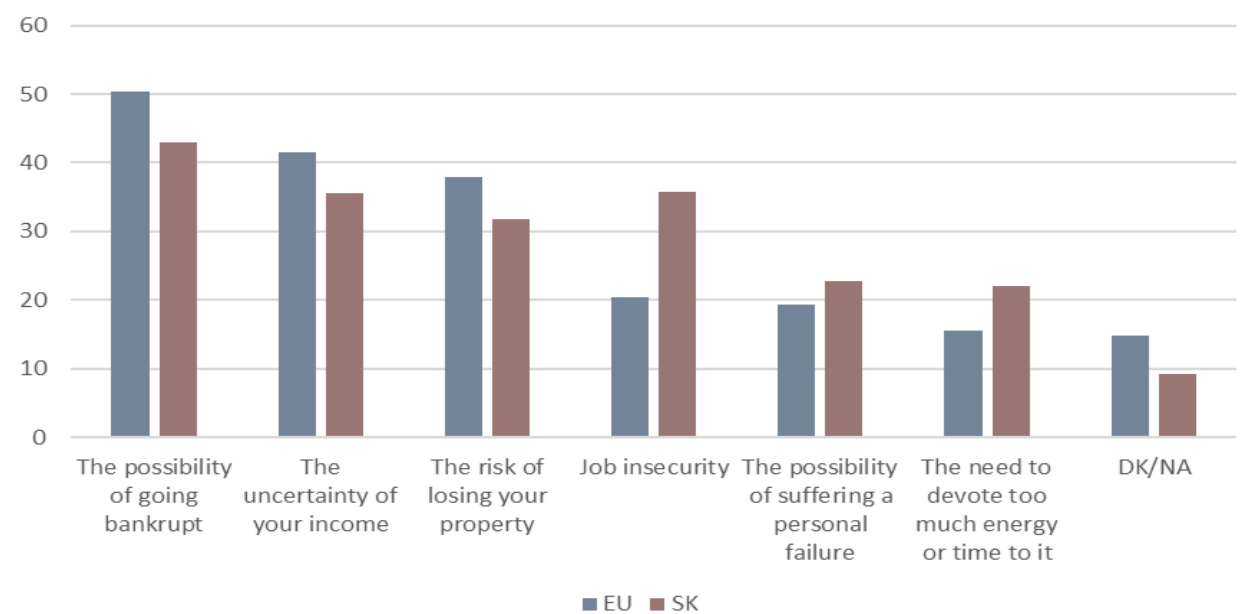

Figure 6. Compares of Barriers of Entry into Business in EU and Slovakia

Source developed by the authors on the basis of Eurobarometer survey.

The results provided by this research and Eurobarometer survey 354 (Flash Eurobarometer: Entrepreneurship in the EU and beyond) showed that the most feared business barriers in the Slovak Republic and the EU were the high financial difficulties associated with business, external factors (in the 
form of tax and contribution burdens) and the internal factors (fear of bankruptcy, loss of property and uncertain income). Khan et al. (2020) claimed that bankruptcy risk is always a constant threat to the SMEs, which determines how long the firms will survive. Koraus et al. (2020) claimed that organizations could influence the individual performance that results in an impact on organizational performance. Besides, it is possible to prevent failure. However, in Slovakia, the tax and levy burden and the perceived corruption rate are still an important barrier for entering the business environment alongside a lack of law enforcement and complicated access to start-up finance. Therefore, it is necessary to pay increased attention to these areas. At the same time, supportive programs for SMEs must continue. The insurance burden, like a barrier, was confirmed. Urbaníkova and Papcunova (2016) claimed that the social security system is a burning issue, and there are often changes in its settings. Social policy has the unique feature of affecting everyone. Papcunova (2011) confirms this persistent situation from the past and states that entrepreneurs have a negative perception of the high levy, poor law enforcement, administrative burden, many unnecessary environmental standards, regulated prices, complicated and frequently changing legislation, corruption and increase in the regulatory burden in connection with the approximation of Slovak legislation to EU law. The development of small and medium-sized enterprises and creating a favourable business environment are essential for building a healthy market-oriented economy. Market conditions and barriers, and start-up support tools, play a major role in this case. A tiny part of entrepreneurs could realize their ideas and succeed in the competitive struggle. Thus, creating a favourable business climate and promoting new and innovative business is essential. The Ministry of Economic of the Slovak Republic supports new forms of business, such as start-ups (Hudakova, 2019). It is clear that this issue represents a wide and comprehensive set of policies, tools, and attitudes, which could be further worked on to create and reveal causal connections, causes, and solutions to improve the business environment and conditions for starting a business in the Slovak Republic. The presented results could be used for further follow-up research in the academic sphere, in which it would be possible to focus on quantifying the effects of individual factors, in-depth analysis of barriers, or identifying attitudes of entrepreneurs at a certain stage of early entrepreneurship (e.g. 1 to 3 years from business start-up).

Conclusions. Results of empiric research confirmed the significant differences between motivational factors for starting doing business. The most important motivational factor influencing decision-making related to becoming an entrepreneur is realizing one's idea, becoming independent, with a higher level of freedom in working time. On the other hand, the most demotivation factors/barriers are the intensity of tax \& fee burden, corruption, and weak law enforcement levels. Therefore, it is necessary to pay attention to these areas. Base on all the mentioned findings, the conclusions identified that there were still significant barriers to enter the business in Slovakia, which considerably limit the further development of doing business in Slovakia. Besides, their scope has increased, especially from the administrative point of view. In turn, it significantly worsened the position of Slovakia in this respect. Similarly to the EU, in Slovakia, there is also scope for using the rescue package as one of the tools for administrative, legal or educational reform. Therefore, that would significantly improve the business environment, remove barriers and stimulate incentives to enter the business in new business sectors in line with new trends in automation, electronification, and less globalization.

Author Contributions. conceptualization, M. F., L. M. and M. M.; methodology, M. F. and M. M.; software, M. M. and M.F.; validation, M. F., M.L. and M. M.; formal analysis, M. L. and M. F.; investigation, M. F. and M. L.; resources, M. F., L. M. and M. K..; data curation, M. F.; writing-original draft preparation, M. F. and M. L.; writing-review and editing, L. M. and M. K.; visualization, M. F.; supervision, M. F. and L. M.; project administration, M. L.; funding acquisition, M. K.

Funding: This research was funded by VEGA scheme, project: Evaluation of local government performance, grant number 1/0407/18. 


\section{References}

Act No. 513/1991 Coll Commercial Code of the Slovak Republic.

Altaxo. (2015). Vstupni a vystupni bariery na trhu. Retrieved from [Link]

Bertan, S. (2020). Key Success Factors for Doing Business in Hot Air Balloon Riding. Journal of Tourism and Services, 20(11), 124-131. [Google Scholar] [CrossRef]

Blstakova, J., Joniakova, Z., Jankelova, N., Stachova, K., \& Stacho, Z. (2020). Reflection of Digitalization on Business Values: The Results of Examining Values of People Management in a Digital Age. Sustainability, 12(12), 5202. [Google Scholar] [CrossRef Bohm-Klein, K. (2015). Co je podnikanie? [Link]

Cavada, M. C., Bobek, V., \& Macek, A. (2017). Motivation factors for female entrepreneurship in Mexico. Entrepreneurial Business and Economics Review, 5(3), 133-148. [Google Scholar] [CrossRef]

Cupido, C. (2003). Barriers to entrepreneurship in the Western Cape (Doctoral dissertation, Cape Technikon). [Google Scholar] Eurobarometer survey . Retrieved from [Link]

Fosic, I., Kristic, J., \& Trusic, A. (2017). Motivational factors: drivers behind women entrepreneurs' decision to start an entrepreneurial venture in Croatia. Scientific Annals of Economics and Business, 64(3), 339-357. [Google Scholar] [Link]

Hofer, A. R., Potter, J., Fayolle, A., Gulbrandsen, M., Hannon, P., Harding, R., ... \& Phan, P. H. (2010). From strategy to practice in university entrepreneurship support. OECD Local Economic and Employment Development (LEED) Papers 2010/9. [Google Scholar] [CrossRef]

Horska, E., Palúchova, J., Prokeinova, R., \& Moiseva, O. A. (2011). Vnimanie imidžu krajiny pôvodu potravinarskych produktov a aspekty ich kvality vo vybranych europskych krajinach, 1st ed. Nitra: Slovak university of Agriculture. [Google Scholar]

Hudakova, J. (2019). Startups support in Slovak Republic. XXI. Mezinarodni kolokvium o regionalnich vědach. Book of Scientific papers. Brno, Czech Republic: Masaryk University, 149-154. [Google Scholar] [CrossRef]

Jakubec, V., Sobekova-Majkova, M., \& Solik, J. (2012). Potreby mladych podnikatel'ov a prekažky v ich podnikani. Bratislava: Združenie mladych podnikatelov Slovenska. Retrieved from [Link]

Junger, J. (2001). Podnikani I. Studijni material. Ostrava: Vysoka skola podnikani.

Kanniainen, V., \& Poutvaara, P. (2007). Imperfect Transmission of Tacit Knowledge and Other Barriers to Entrepreneurship. Comparative Labor Law \& Policy Journal, 28(4). [Google Scholar]

Karnreungsiri, I., \& Praditsuwan, N. (2017). Motivational and Success Factors of Women Entrepreneurs: A Case Study of Small and Medium Enterprises in Manufacturing Sector of Thailand. 3rd RSEP Multidisciplinary International Conferences on Social Issues and Economic Studies: 17-27. Retrieved from [Link]

Ketko, N. V., \& Akimova, O. E. (2016). Analyzing, evaluating and ranking of motivational preferences of entrepreneurs in small business development. Actual Problems of Economics, 1, 361-369. [[Google Scholar]]

Khan, K. A., Dankiewicz, R., Kliuchnikava, Y., \& Olah, J. (2020). How Do Entrepreneurs Feel Bankruptcy?. International Journal of Entrepreneurial Knowledge, 8(1), 89-101. [Google Scholar] [[CrossRef]]

Klapper, L., Laeven, L., \& Rajan, R. (2006). Entry regulation as a barrier to entrepreneurship. Journal of financial economics, 82(3), 591-629. [Google Scholar] [Google Scholar]

Koraus, A., Gombar, M., Kelemen, P., \& Backa, S. (2019). Using quantitative methods to identify security and unusual business operations. Entrepreneurship and sustainability issues, 6 (3), 1101-1112 [Google Scholar]

Koraus, A., Kascakova, Z., \& Felcan, M. (2020). The Impact Of Ability-Enhancing Hrm Practices On Perceived Individual Performance In It Industry In Slovakia. Central European Journal of Labour Law and Personnel Management, 3(1), 34-46. [Google Scholarl [CrossRef

Koraus, A., Veselovska, S., \& Kelemen, P. (2017). Cyber security as part of the business environment. Zbornik z konferencie Medzinarodné vztahy 2017: Aktualne otazky svetovej ekonomiky a politiky. [Google Scholar]

Lukes, M. (2013). Entrepreneurs as Innovators: A Multi-Country Study on Entrepreneurs' Innovative Behaviour. Prague Economic Papers, 22(1), 72-84. [Google Scholar] [CrossRef]

Lukes, M., Zouhar, J., Jakl, M., \& Ocko, P. (2013). Faktory ovlivnující vstup do podnikaní: zacínající podnikatelé v Ceské republice. Politicka ekonomie, 61(2), 229-247. [Google Scholar]

Majkova, M. S. (2011). Analýza bariér a faktorov financovania malých a stredných podnikov v Slovenskej republike. Ekonomický casopis, 59(10), 1033-1049. [Google Scholar]

Moriano, J. A., Topa, G., Molero, F., Entenza, A. M., \& Mangin, J. P. L. (2012). Autoeficacia para el liderazgo emprendedor. Adaptacion y validacion de la escala CESE en España. Anales de Psicologia/Annals of Psychology, 28(1), 171-179. [Google Scholar]

Mura, L., \& Rozsa, Z. (2013). The impact of networking on the innovation performance of SMEs. In Löster, T. and Pavelka, T., The 7th International Days of Statistics and Economics: Conference Proceedings. Prague, Czech Republic (pp. 19-21). [[Google Scholarl]

Mushtaq, M. (2017). The top three barriers to enterpreneurial success and how to overcome them. London: Virgin Group. Retrieved from [Link] 
Papcunova, V. (2011). Statna sprava a jej nastroje pre podporu maleho a stredneho podnikania. Ekonomika polnohospodarstva. 11(4): 30-39.

Papula, J., \& Papulova, E. (2002). Podnikanie. Bratislava. Kartprint.

Peracek, T. (2019). Why Is a Simple Company on Shares an Unnecessary Type of Business? Conference: 33rd InternationalBusiness-Information-Management-Association (IBIMA). Education excellence and innovation management through Vision 2020.

PwC. (2010). Pro ceske podnikatele může byt snažsi zvladnout hospodaRskou krizi, než uRidit růst sve firmy. Prague: PwC

Qunlian, L. (2011). The major difficulties and countermeasures of current university graduates' entrepreneurship in China. Journal of Chinese Entrepreneurship, 3(3): 228-239. [Google Scholar] [CrossRef]

Ramayah, T., \& Harun, Z. (2005). Entrepreneurial intention among the student of Universiti Sains Malaysia (USM). International Journal of Management and Entrepreneurship, 1(1), 8-20. [Google Scholar]

Rimarcik, M. (2007). Statistika pre prax. 1st ed. Kosice, Slovakia: Marian Rimarcik.

Sandhu, M. S., Sidique, S. F., \& Riaz, S. (2011). Entrepreneurship barriers and entrepreneurial inclination among Malaysian postgraduate students. International journal of entrepreneurial behavior \& research, 17(4): 428-449. [Google Scholar] [CrossRef]

Schumpeter, J. A. (1983). The Theory of Economic Development: An Inquiry Into Profits, Capital, Credit, Interest and the Business Cycle. New Brunswick, NJ: Transaction Publishers.

Sheskin, D. J. (2020). Handbook of parametric and nonparametric statistical procedures (5. Ed). New York: CRC Press. [Google Scholar]

Srovnalikova, P. (2017). Specifics of Family Businesses and Problems of their Financing. International scientific conference for doctoral students and post-doctoral scholars (EDAMBA 2017): Knowledge and skills for sustainable development: the role of economics, business, management and related disciplines, 428-436.

Srpova, J., \& Rehor, V. (2010). Zaklady podnikani. Praha : Grada Publishing. Retrieved from [Link]

Stiglic, M. (2009). Neparametricke statisticke metody a ich ekonomicke aplikacie. In Book of Scientific Papers of Students Scientific Conference Slovak Technical University in Bratislava. Paper presented at Studentska vedecka Konferencia Akademicky rok 2008/2009. Retrieved from [CrossRef]

The World Bank. (2009). Doing Business 2009. Retrieved from [Link]

The World Bank. (2009). Doing Business 2009. Retrieved from [Link]

The World Bank. (2010). Doing Business 2010. Retrieved from [Link]

The World Bank. (2011). Doing Business 2011. Retrieved from [Link]

The World Bank. (2012). Doing Business 2012. Retrieved from [LInk

The World Bank. (2013). Doing Business 2013. Retrieved from [Link]

The World Bank. (2014). Doing Business 2014. Retrieved from [Link]

The World Bank. (2015). Doing Business 2015. Retrieved from [Link

The World Bank. (2016). Doing Business 2016. Retrieved from [Link]

The World Bank. (2017). Doing Business 2017. Retrieved from [Link]

The World Bank. (2018). Doing Business 2018. Retrieved from [Link]

The World Bank. (2019). Doing Business 2019. Retrieved from [Link

Thompson, E. R., \& Penny, M. J. (2013). The Human Machine: Secrets of Success. Scotts Valley, CA: CreateSpace Independent Publishing Platform. Retrieved from [Link]

Timmons, M. (2002). Moral Theory an Introduction. Oxford: Rowman \& Littlefield Publishers. [Google Scholar]

Toman, I. (2010). Motivace zvenci je jako smrad za par hodin se vyvětra. Bratislava: Taxus International.]

Urbanikova, M., \& Papcunova, V. (2016). Pension Systems in Slovakia and Its Sustainability. Geographical Information, 20(2), 341-351. [Google Scholar]

Urbanikova, M., \& Stubnova, M. (2020). Analysis of Wage Inequalities in the Slovak Republic at the Regional Level. In: XXIII. mezinarodni kolokvium o regionalnich vědach. Sbornik pRispěvkủ. Brno, Masaryk University. [CrossRef]

Милан Філья, доцент, Ph.D., Університет імені Костянтина Філософра в Нітрі, Словацька республіка

Міхаїл Левицкий, Ph.D., Університет імені Костянтина Філософра в Нimpi, Словацька республіка

Ладислав Мура, Ph.D., доцент, Пан-Європейський університет в Братиславі, Словацька республіка

Милан Марош, Ph.D., Університет імені Костянтина Філософа в Нітрі, Словацька республіка

Марцела Коренкова, Ph.D., Університет імені Костянтина Філософа в Нітрі, Словацька республіка

Інновації в бізнес-управлінні: мотиваційні фактори та бар'єри

у статті проаналізовано ефективність функиіонування підприємницької сектору як однієї із рушійних сил економічного розвитку країни. Авторами відмічено, що підприємницький сектор генерує найбільшу питому вагу ВВП за рахунок податків від реалізації продукції. Ефективний розвиток підприємництва вимагає формування сприятливого бізнес-клімату для відкриття власної справи та виходу на ринок. Метою статті є оцінювання впливу мотиваційних факторів та бар'єрів на розвиток підприємницького сектору. У ході дослідження проаналізовано методи управління бізнес-середовищем та фрінансовою діяльністю з точки зору менеджменту, інновацій, ініціативності та підтримки підприємницької діяльності. Методологічним інструментарієм дослідження є класичні методи наукового аналізу, синтез та методи збору даних. У роботі застосовано базовий евристичний підхід для аналізу наукового доробку щодо 
проблематики дослідження та моніторингу показників бізнес-клімату та розвитку малого та середнього підпиємництва у Словацькій республіці, у країнах ЄС-27 та світі. Вихідні дані для дослідження сформовано на основі даних Європейської комісії, звіту Flash Eurobarometer та Світового банку. Детерміновану вибірку даних сформовано на основі результатів опитування 426 респондентів Словацької республіки. Перевірку гіпотез дослідження здійснено за допомогою критеріїв Фрідмана, Колмогорова-Смирнова та Краскела-Уолліса. Результати емпіричного аналізу засвідчили про наявність суттєвої відмінності впливу між мотиваційними фракторами при відкритті власної справи. Авторами встановлено, що у Словацькій республіці існують суттєві бар'єри, які значно обмежують подальший розвиток бізнесу. За результатами дослідження виокремлено низку рекомендацій щодо покращення поточного стану бізнессередовища, шляхом підтримки мотиваційних факторів та подолання бар'єрів при відкритті власної справи у Словацькій республіці.

Ключові слова: мале та середнє підприємництво, інновації, бар'єри, бізнес, управління бізнесом.

Manuscript received: 27.01.2020

(C) The author(s) 2020. This article is published with open access at Sumy State University 